\title{
Inkjet Printing as High-Throughput Technique for the Fabrication of $\mathrm{NiCo}_{2} \mathrm{O}_{4}$ Films
}

\author{
Reyna Dianela Bacelis-Martínez, ${ }^{1}$ Gerko Oskam, ${ }^{1}$ \\ Geonel Rodriguez Gattorno, ${ }^{1}$ and Miguel Angel Ruiz-Gómez ${ }^{1,2}$ \\ ${ }^{1}$ Department of Applied Physics, CINVESTAV-IPN, 97310 Mérida, YUC, Mexico \\ ${ }^{2}$ CONACYT-Department of Applied Physics, CINVESTAV-IPN, 97310 Mérida, YUC, Mexico
}

Correspondence should be addressed to Geonel Rodriguez Gattorno; geonelr@cinvestav.mx and Miguel Angel Ruiz-Gómez; miguel.ruiz@cinvestav.mx

Received 31 March 2017; Revised 25 May 2017; Accepted 31 May 2017; Published 6 July 2017

Academic Editor: Ilia Ivanov

Copyright ( 2017 Reyna Dianela Bacelis-Martínez et al. This is an open access article distributed under the Creative Commons Attribution License, which permits unrestricted use, distribution, and reproduction in any medium, provided the original work is properly cited.

\begin{abstract}
Owing to its distinctive physicochemical properties, nickel-cobalt mixed oxide $\left(\mathrm{NiCo}_{2} \mathrm{O}_{4}\right)$ has become a promising and innovative material for applications in many technological fields. The design of fast and reliable techniques for the deposition of this material is essential in the development of applications. In this work, $\mathrm{NiCo}_{2} \mathrm{O}_{4}$ films were successfully prepared by an inkjet printing technique using a suitable ink obtained from metal nitrates in a glycerol-water mixture. In order to deposit well-defined and uniform film patterns, the instrumental parameters such as drop spacing and inkjet voltage have been explored. The pure crystalline bimetallic nickel cobaltite oxide is obtained at $500^{\circ} \mathrm{C}$ with a homogeneous compositional distribution along the film. The average thickness observed by scanning electron microscopy is around $490 \mathrm{~nm}$, whereas X-ray photoelectron spectroscopy analysis revealed that the film surface presents mixed oxidation states for both metals: $\mathrm{Co}^{2+}, \mathrm{Co}^{3+}, \mathrm{Ni}^{2+}$, and $\mathrm{Ni}^{3+}$. The electrocatalytic performance of inkjet-printed $\mathrm{NiCo}_{2} \mathrm{O}_{4}$ films for the water oxidation reaction is comparable with earlier reports.
\end{abstract}

\section{Introduction}

$\mathrm{NiCo}_{2} \mathrm{O}_{4}$ oxide has recently been a motivating topic from the viewpoint of materials science because of its interesting catalytic, electrical, and optical properties. These properties are related to important technological applications such as electrodes for fuel cells $[1,2]$, electrodes in sodiumand lithium-ion batteries [2-4], optoelectronic [5, 6] and magnetic devices [7, 8], supercapacitors [4, 9-13], flat-panel displays $[2,14]$, infrared transparent conducting materials $[2,5,14]$, glucose sensors [15], and several electrochemical reactions $[1,6,7,16-20]$. In particular, the production of clean energy from renewable sources as in the electrocatalytic water splitting process is an attractive alternative for an energy economy based on hydrogen $[20,21]$. However, for practical applications, it is necessary to develop high performance electrocatalysts by using nonprecious metals for both the anodic oxygen evolution reaction (OER) and the cathodic hydrogen evolution reaction (HER) [17, 19, 22]. Specifically, efficient and stable electrocatalysts are required for the anodic half-reaction due to the multielectron transfer needed for water oxidation, which is important to improve the overall water splitting process $[17,20,22]$. In this regard, $\mathrm{NiCo}_{2} \mathrm{O}_{4}$ as a cobaltite spinel has shown excellent electrocatalytic properties, because the mixed oxidation states of its cations favor the adsorption of water and hydroxide ions. Also, it facilitates the permeability and uptake reversibility of oxygen and provides active sites for chemisorption $[1,17,22]$. Recently, $\mathrm{NiCo}_{2} \mathrm{O}_{4}$ was reported as an efficient bifunctional material for both the OER and the HER, being regarded as a very active nonprecious metal electrocatalyst [22]. In addition, other significant advantages of $\mathrm{NiCo}_{2} \mathrm{O}_{4}$ to be considered are its better electrochemical properties and electrical conductivity compared with pure $\mathrm{NiO}$ or $\mathrm{Co}_{3} \mathrm{O}_{4}$ oxides $[1,4,9]$. Moreover, its constituent metals are earth-abundant, cheap, and not toxic $[4,10,22]$.

Many of the above-mentioned applications of $\mathrm{NiCo}_{2} \mathrm{O}_{4}$ require its fabrication in thin film form; moreover, taking 
into consideration a possible scale-up, the surface dimensions of the film is an important issue. In this respect, $\mathrm{NiCo}_{2} \mathrm{O}_{4}$ films have been principally prepared by physical deposition processes such as pulsed laser deposition [16, 23-25] and radio frequency magnetron sputtering $[5,8]$, as well as by means of chemical routes including electrodeposition $[6,14$, 15], sol-gel [2], hydrothermal synthesis [26], spray pyrolysis [4], and chemical vapor deposition [27]. In general, if cost of the process and equipment requirements are considered, the solution-based chemical methods are more appropriate than physical routes. As a part of the solution-based chemical approaches, inkjet printing recently has gained a lot of acceptance in many areas of science and engineering as a high-throughput deposition technique for fabrication of thin films and devices [28-33]. This technique is able to overcome several difficulties presented by traditional routes, generating new functionalities and performance. Some important advantages are as follows: (i) negligible materials waste, therefore, it is an environment-friendly and low cost route; (ii) a noncontact method, hence, it minimizes film contamination; and (iii) the possibility of depositing an exact amount of material in a pattern previously designed. In particular, the piezoelectric drop-on-demand inkjet printer ejects the ink only when it is required with generation of droplets within $20-50 \mu \mathrm{m}$ in size, achieving high placement accuracy of drops favoring the formation of good quality micrometric patterns. Also, these characteristics allow the preparation of continuous films specifically designed with a size of several centimeters.

It is known that, in the inkjet printing technique, the quality of the prepared films depends considerably on the physicochemical properties of the ink used during the process as well as several printing parameters that need to be optimized. This paper is focused on the formulation and analysis of a suitable ink used in a drop-on-demand materials printer, where the parameters drop spacing and jetting voltage were evaluated in order to obtain a homogeneous $10 \mathrm{~mm} \times 10 \mathrm{~mm}$ $\mathrm{NiCo}_{2} \mathrm{O}_{4}$ film. The properties of the films were determined by several physicochemical characterization techniques and the electrocatalytic activity of the most uniform films was tested in the water oxidation reaction.

\section{Materials and Methods}

The ink was prepared dissolving $0.5814 \mathrm{~g} \mathrm{Ni}\left(\mathrm{NO}_{3}\right)_{2} \cdot 6 \mathrm{H}_{2} \mathrm{O}$ and $1.1621 \mathrm{~g} \mathrm{Co}\left(\mathrm{NO}_{3}\right)_{2} \cdot 6 \mathrm{H}_{2} \mathrm{O}$ (Sigma Aldrich $\geq 97 \%$ ) in a mixture of glycerol: deionized water (65:35 wt.\%) at room temperature. The ink was analyzed by UV-Vis spectroscopy (Agilent Instruments) in the range of 200-800 nm. The rheological properties were determined by means of a KinexusPro rheometer operated at $35^{\circ} \mathrm{C}$ using $\sim 1 \mathrm{~mL}$ of ink; the frequency range was $0.01-100 \mathrm{~s}^{-1}$. The thermogravimetric and differential scanning calorimetric (TGA-DSC) analysis was performed on a TA Instruments-Discovery equipment with a heating rate of $5^{\circ} \mathrm{C} / \mathrm{min}$ within $50-500^{\circ} \mathrm{C}$ under air flow at $25 \mathrm{~mL} / \mathrm{min}$. Before printing, the FTO (fluorinedoped tin oxide) Pilkington TEC $8 \Omega /$ sq. substrates were cleaned using a piranha solution for $10 \mathrm{~min}$ and rinsed with deionized water. Inkjet printing was realized using a drop-on-demand Dimatix materials printer DMP-2831 (Fujifilm) and a DMC-11610 piezoelectric cartridge (16 nozzles and $254 \mu \mathrm{m}$ spacing) filled with $1.5 \mathrm{~mL}$ of our formulated ink. A $10 \times 10 \mathrm{~mm}^{2}$ continuous square pattern was printed, varying the jetting voltage ( 25 and $35 \mathrm{~V}$ ) and drop spacing (15, 20 , and $30 \mu \mathrm{m}$ ), maintaining the platen temperature at $40^{\circ} \mathrm{C}$. In addition, some demonstrative patterns of micrometric dots and lines were inkjet-printed. All the obtained deposits were heat treated from 30 to $500^{\circ} \mathrm{C}$ with a ramp of $2^{\circ} \mathrm{C} / \mathrm{min}$ and kept at 200,300 , and $500^{\circ} \mathrm{C}$ during 30, 30, and $60 \mathrm{~min}$, respectively. The morphology and chemical composition were analyzed by scanning electron microscopy and energy dispersive X-ray spectroscopy (SEM-EDS) using a JEOL JSM7600F microscope and X-Max Oxford Instruments detector. The crystalline phase was determined using a Siemens D5000 diffractometer with $\mathrm{Cu} \mathrm{K} \alpha$ radiation $(\lambda=1.5418 \AA$ ). X-ray diffraction $(\mathrm{XRD})$ data were collected at room temperature from 30 to $70^{\circ}$ with grazing-angle incidence of $1^{\circ}$, step size of $0.02^{\circ}$, step time of $3 \mathrm{~s}, 34 \mathrm{kV}$, and $25 \mathrm{~mA}$. Oxidation states and quantification were examined by using X-ray photoelectron spectroscopy (XPS) on a K-Alpha (Thermo Scientific) spectrometer, employing monochromatized $\mathrm{Al}$ $\mathrm{K} \alpha$ radiation ( $1486.6 \mathrm{eV}$ ) and double-focusing hemispherical analyzer. The electronic absorption spectra were measured in five zones of the films with an UV-Vis-NIR microspectrophotometer (MSP500RT, Angstrom Sun Technologies) within $400-1000 \mathrm{~nm}$ with a $40 \mathrm{x}$ objective and spot size of $10 \mu \mathrm{m}$; an FTO substrate was used as reference. Electrochemical analysis was carried out using an Autolab PGSTAT302N/FRA2 (Metrohm Autolab) apparatus and a system with the inkjetprinted film as working electrode, $\mathrm{Ag} / \mathrm{AgCl}(3 \mathrm{M})$ as reference electrode, and a platinum wire as counterelectrode. Linearscanning voltammetry was performed in $0.1 \mathrm{M} \mathrm{KOH}$ solution, within $0-0.7 \mathrm{~V}$ and at a scan speed of $5 \mathrm{mV} / \mathrm{s}$.

\section{Results and Discussion}

3.1. Ink Physicochemical Properties. The formulated ink is a reddish and homogeneous solution (see inset photograph in Figure 1(a)) with excellent stability and without formation of any sediment for three months under regular storage conditions $\left(25^{\circ} \mathrm{C}\right.$ and light protected). Figure 1(a) depicts the UV-Vis spectrum of the ink, where absorption bands at 229 and $297 \mathrm{~nm}$ match with electronic transitions from nonbonding (lone-pair) $n$ orbital to an antibonding $\pi$ orbital ( $n-\pi^{*}$ transitions), typical of nitrate ions. The bands at 394, 468 , and $513 \mathrm{~nm}$ correspond to $\mathrm{d}-\mathrm{d}$ transitions of a cobalt aquo-complex $\left(\left[\mathrm{Co}\left(\mathrm{H}_{2} \mathrm{O}\right)_{6}\right]^{2+}\right)$, whereas the bands at 654 and $730 \mathrm{~nm}$ are related to a nickel aquo-complex $\left(\left[\mathrm{Ni}\left(\mathrm{H}_{2} \mathrm{O}\right)_{6}\right]^{2+}\right)$. This is relevant since the UV-Vis spectrum allows us to follow the ink stability with time.

Analysis of the rheological properties of the ink was carried out, and, according to the plot of shear stress versus shear rate, Figure 1(b), a slight deviation from Newtonian behavior is observed. From Figure 1(c) of the viscosity versus shear rate, a high-frequency viscosity value of the ink of $5.7 \mathrm{mPa} \cdot \mathrm{s}$ was estimated; this value is close to the reported value for a glycerol : water (65:35 wt.\%) mixture [34]. Figure 1(d) presents the plot of shear modulus versus frequency, where 


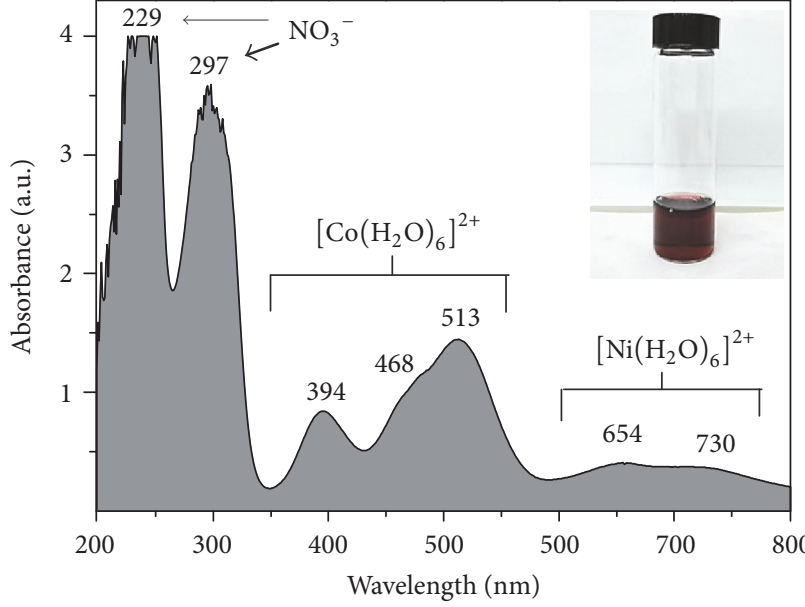

(a)

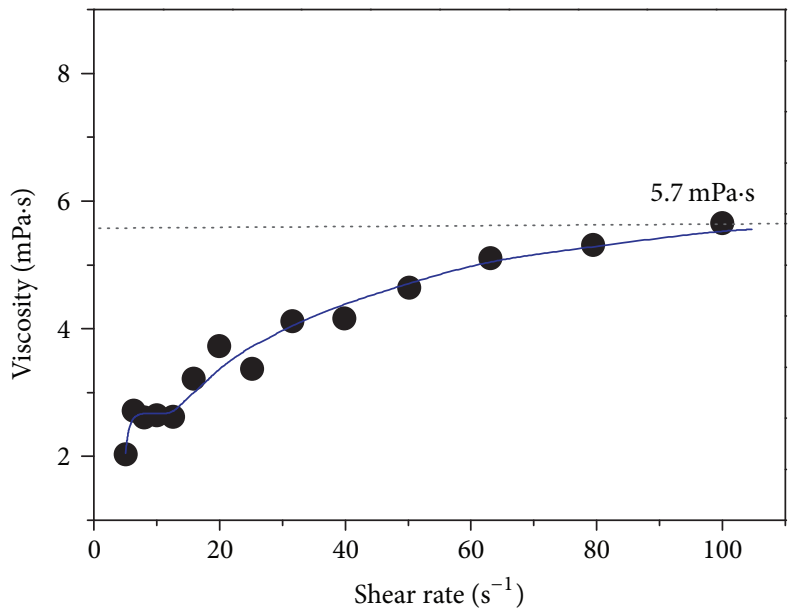

(c)

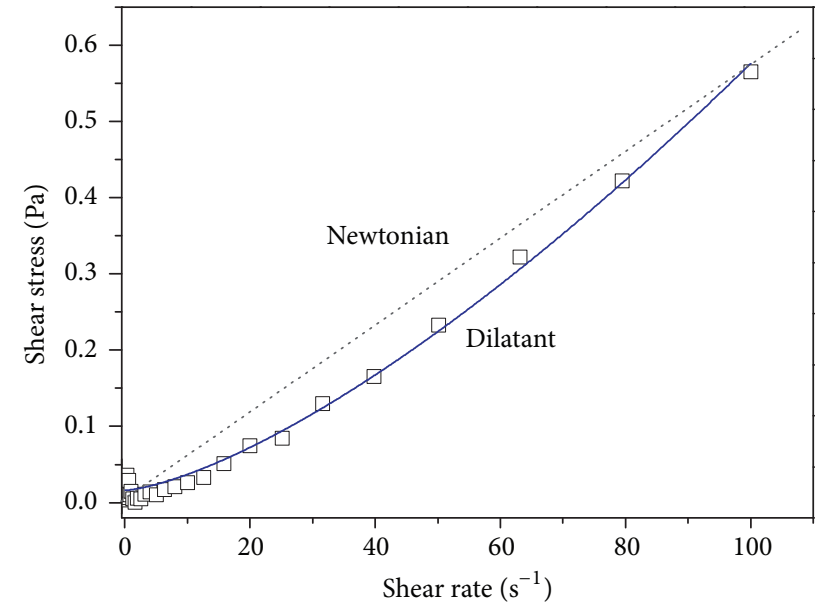

(b)

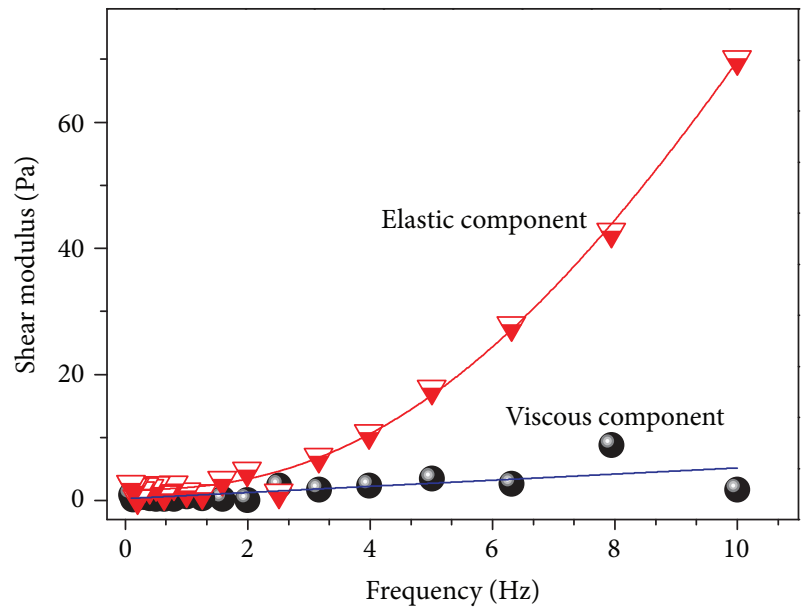

(d)

FIGURE 1: (a) UV-Vis absorption spectrum of the formulated ink; (b) shear rate versus shear stress; (c) viscosity as function of the shear rate; (d) shear modulus (viscous and elastic components) versus frequency.

the elastic component is larger than the viscous component with increasing frequency, which means that the ink behaves like a solid at higher frequencies. On the other hand, as literature indicates for a glycerol : water ( $65: 35 \mathrm{wt} . \%)$ mixture, the surface tension of the ink is expected to be around 65 dynes $/ \mathrm{cm}$ [34]. Considering that physicochemical characteristics of an ink (viscosity and surface tension) play an important role for appropriate jetting during the printing process, it is likely that the glycerol-water formulated ink presents good performance, as the values are close to those required for a drop-on-demand piezoelectric inkjet printer [35]. In addition, the higher boiling point $\left(\sim 290^{\circ} \mathrm{C}\right)$ and heat of vaporization $(\sim 89 \mathrm{~kJ} / \mathrm{mol})$ of glycerol in comparison to water $\left(\sim 100^{\circ} \mathrm{C}\right.$ and $\left.\sim 40 \mathrm{~kJ} / \mathrm{mol}\right)$ suggests a low evaporation rate of the inkjet-printed drops favoring deposition of a homogeneous and continuous film on the substrate.

In order to establish the annealing procedure after inkjet printing, a thermal analysis was performed. The thermogravimetric curve shown in Figure 2(a) suggests that the ink decomposes in three stages; the first step occurs between
30 and $95^{\circ} \mathrm{C}$ with a sharp weight loss of $55.7 \%$, and this is due to partial evaporation of the water-glycerol mixture. After water evaporation, the ink has a higher proportion of glycerol, and the second weight loss step of $39.2 \%$ is observed from 95 to $255^{\circ} \mathrm{C}$. Finally, the third step takes place at $325^{\circ} \mathrm{C}$ accompanied by a weight loss of $2.8 \%$, which corresponds to decomposition of nitrates present in the ink. Figure 2(b) exhibits the DSC curve, showing two endothermic and one exothermic peaks at $36.1,150.6$, and $260.7^{\circ} \mathrm{C}$, respectively. The exothermic event could be related to partial oxidation of $\mathrm{Ni}^{2+}$ and $\mathrm{Co}^{2+}$ as well as a probable transformation of NO to $\mathrm{NO}_{2}$. After $375^{\circ} \mathrm{C}$, no events were observed in both TGA and DSC curves. The obtained information from this analysis is important because it allows choosing the most adequate temperatures for drying and calcination in order to obtain a homogeneous film with the desired crystal phase.

3.2. Inkjet-Printed $\mathrm{NiCO}_{2} \mathrm{O}_{4}$ Films. Besides the ink properties, the printing settings must be optimized for each ink to obtain good quality films. In this work, different values of 


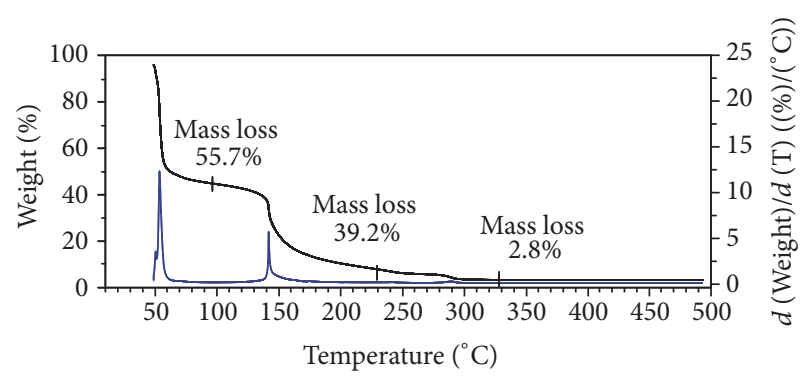

(a)

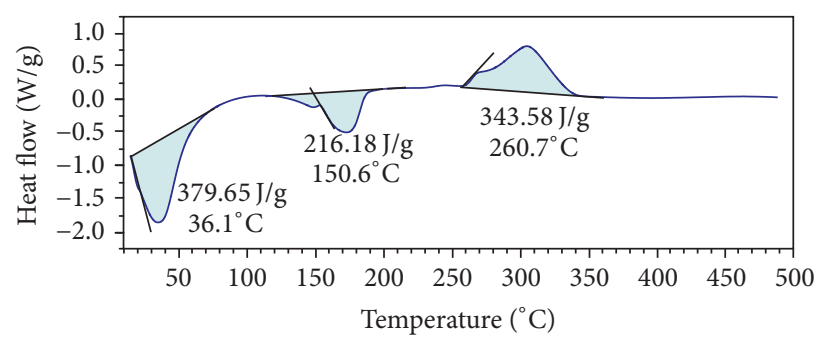

(b)

FIgURE 2: Thermal analysis curves of the formulated ink: (a) thermogravimetric curve and (b) differential scanning calorimetric curve.

drop spacing (DS) and jetting voltage (JV) were evaluated. Taking into consideration both a visual and a microscopic inspection, after a thermal treatment at $500^{\circ} \mathrm{C}$ during 1 hour, the best result was obtained for a inkjet-printed film using $\mathrm{DS}=20 \mu \mathrm{m}$ and $\mathrm{JV}=35 \mathrm{~V}$. For that reason, this is the representative film that will be further analyzed in this work, referred to hereafter as F-20-35. The DS parameter is related to the number of jetted drops per area and therefore to the pattern resolution; for example, a DS value of $20 \mu \mathrm{m}$ corresponds to 2,510 drops $/ \mathrm{mm}^{2}$ and 1,270 dots per inch (dpi). Thus, if DS is low (e.g., $15 \mu \mathrm{m}$ ), an overspreading of the ink on substrate occurs, provoking that the pattern shape is undefined; whereas if DS is high (e.g., $30 \mu \mathrm{m})$, the drops do not interact with each other and do not coalesce to form a continuous film. On the other hand, JV principally controls drop velocity, where increasing JV increases velocity. This parameter should be adjusted depending on the physical properties of the ink. In our formulated ink, a high JV of $35 \mathrm{~V}$ ( $40 \mathrm{~V}$ is the upper limit in the printer) was required because of the high value ( 65 dynes $/ \mathrm{cm}$ ) of the surface tension; the recommended range is $35-70$ dynes $/ \mathrm{cm}$.

A photograph of a representative $\mathrm{F}-20-35 \mathrm{NiCo}_{2} \mathrm{O}_{4}$ film is presented in Figure 3(a), where a black coating with a well-defined $10 \mathrm{~mm} \times 10 \mathrm{~mm}$ square is observed, while SEM imaging and EDS mapping analysis of the surface reveal a continuous coating formed by nanoparticles interconnected to each other with a homogenous elemental distribution.

The quantitative EDS results indicate an atomic percentage of 7.94, 16.05, and 76.01 for nickel, cobalt, and oxygen, respectively; therefore, the proportion nickel : cobalt is $1.00: 2.02$ in good agreement with the stoichiometry of $\mathrm{NiCo}_{2} \mathrm{O}_{4}$ oxide. Also, the thickness was obtained from a cross-sectional SEM image (see Figure 3(b)), obtaining an average value of $490 \mathrm{~nm}$. In order to confirm the film homogeneity, a linear-scanning EDS analysis of the cross section was done, where nickel, cobalt, and oxygen are homogeneously distributed with the same proportion observed in the surface analysis results. Table 1 lists a summary of some of the typical synthesis methods for fabrication of $\mathrm{NiCo}_{2} \mathrm{O}_{4}$ films, their thickness values, and XRD phase purity, as well as their specific applications and properties. As can be seen in Table 1, the thickness of the inkjet-printed F-20-35 $\mathrm{NiCo}_{2} \mathrm{O}_{4}$ films is comparable with those obtained previously by both physical and chemical approaches.

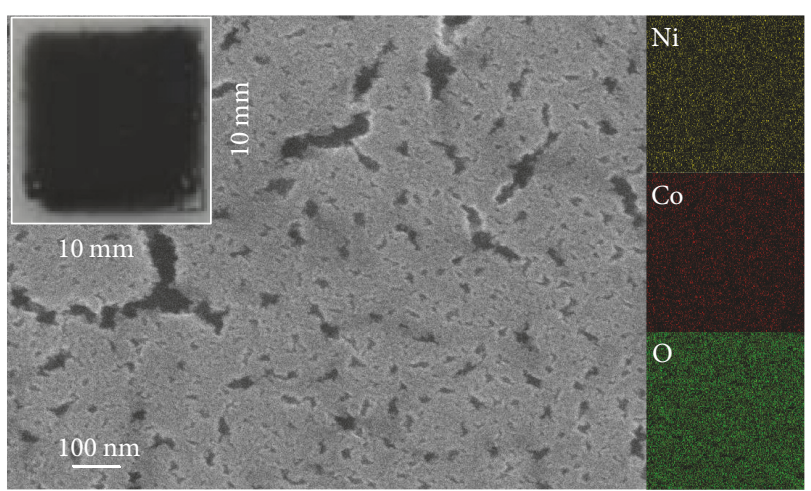

(a)

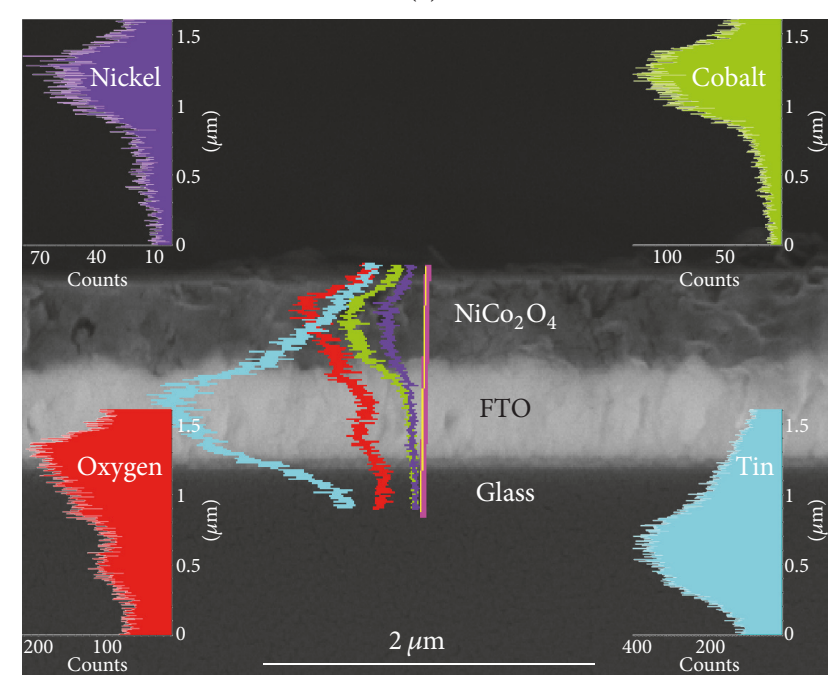

(b)

FIGURE 3: (a) SEM micrograph using secondary-electron mode and elemental chemical mapping of the film surface (upper left inset is a photograph of the deposited sample) and (b) cross-sectional SEM image using the low-angle back-scattered electron mode and EDS line scan.

In order to confirm the micrometric resolution achieved with the inkjet printing technique, Figure 4 presents representative optical and SEM images of dots and line patterns of inkjet-printed $\mathrm{NiCo}_{2} \mathrm{O}_{4}$ on FTO using the optimized parameters for our ink. The micrographs reveal well-defined dot arrays (Figures $4(\mathrm{a})-4(\mathrm{c})$ ), where the dots are separated at 
TABLE 1: Summary of reports on $\mathrm{NiCo}_{2} \mathrm{O}_{4}$ films prepared by different techniques.

\begin{tabular}{|c|c|c|c|c|c|c|}
\hline Synthesis method & Precursors & Substrate & Thickness & XRD phase & Application/properties & Ref. \\
\hline Inkjet printing & $\begin{array}{c}\mathrm{Ni}\left(\mathrm{NO}_{3}\right)_{2} \cdot 6 \mathrm{H}_{2} \mathrm{O} \\
\mathrm{Co}\left(\mathrm{NO}_{3}\right)_{2} \cdot 6 \mathrm{H}_{2} \mathrm{O} \\
\text { Glycerol, deionized water }\end{array}$ & FTO & $490 \mathrm{~nm}$ & Pure & $\begin{array}{l}\text { Water oxidation } \\
\text { reaction }\end{array}$ & This work \\
\hline RF sputtering & Ni-Co metal alloy targets & Silicon & $550-830 \mathrm{~nm}$ & Impure & Electrical and magnetic & {$[8]$} \\
\hline $\begin{array}{l}\text { Pulsed laser } \\
\text { deposition }\end{array}$ & $\begin{array}{c}\text { Polycrystalline } \mathrm{NiCo}_{2} \mathrm{O}_{4} \\
\text { target }\end{array}$ & $\mathrm{MgAl}_{2} \mathrm{O}_{4}(001)$ & $240 \mathrm{~nm}$ & Pure & Electrical and magnetic & {$[16]$} \\
\hline Spray pyrolysis & $\begin{array}{c}\mathrm{Ni}\left(\mathrm{NO}_{3}\right)_{2} \cdot 6 \mathrm{H}_{2} \mathrm{O} \\
\mathrm{Co}\left(\mathrm{NO}_{3}\right)_{2} \cdot 6 \mathrm{H}_{2} \mathrm{O} \\
\text { Methanol } \\
\end{array}$ & Aluminum foil & $12 \mu \mathrm{m}$ & Pure & Mesoporosity & {$[36]$} \\
\hline Sol-gel & $\begin{array}{c}\mathrm{Co}\left(\mathrm{CH}_{3} \mathrm{COO}\right)_{2} \cdot 4 \mathrm{H}_{2} \mathrm{O} \\
\mathrm{Ni}\left(\mathrm{CH}_{3} \mathrm{COO}\right)_{2} \cdot 4 \mathrm{H}_{2} \mathrm{O} \\
\text { 2-Methoxyethanol } \\
\text { Ethanolamine }\end{array}$ & $\mathrm{Al}_{2} \mathrm{O}_{3}(0001)$ & $900-1000 \mathrm{~nm}$ & Impure & Electrical resistivity & {$[2]$} \\
\hline Hydrothermal & $\begin{array}{c}\mathrm{Ni}\left(\mathrm{NO}_{3}\right)_{2} \cdot 6 \mathrm{H}_{2} \mathrm{O} \\
\mathrm{Co}\left(\mathrm{NO}_{3}\right)_{2} \cdot 6 \mathrm{H}_{2} \mathrm{O} \\
\text { Urea, } \mathrm{NH}_{4} \mathrm{~F} \text {, deionized } \\
\text { water }\end{array}$ & FTO & $1-4.5 \mu \mathrm{m}$ & Pure & $\begin{array}{l}\text { Dye sensitized solar } \\
\text { cells }\end{array}$ & {$[26]$} \\
\hline $\begin{array}{l}\text { Chemical bath } \\
\text { deposition }\end{array}$ & $\begin{array}{c}\mathrm{NiCl}_{2} \cdot 6 \mathrm{H}_{2} \mathrm{O} \\
\mathrm{CoCl}_{2} \cdot 6 \mathrm{H}_{2} \mathrm{O} \\
\text { Deionized water } \\
\mathrm{KOH}(\text { electrolyte }) \\
\end{array}$ & Stainless steel & $2.3-18 \mu \mathrm{m}$ & Pure & Supercapacitors & {$[37]$} \\
\hline Electrodeposition & $\begin{array}{l}\mathrm{Ni}\left(\mathrm{NO}_{3}\right)_{2} \cdot 6 \mathrm{H}_{2} \mathrm{O} \\
\mathrm{Co}\left(\mathrm{NO}_{3}\right)_{2} \cdot 6 \mathrm{H}_{2} \mathrm{O} \\
\text { Deionized water } \\
\mathrm{KCl} \text { (electrolyte) }\end{array}$ & $\begin{array}{l}\text { Stainless steel } \\
\text { and Indium-Tin } \\
\text { Oxide (ITO) }\end{array}$ & $4 \mu \mathrm{m}$ & Pure & Methanol fuel cells & {$[6]$} \\
\hline Electrodeposition & $\begin{array}{l}\mathrm{Ni}\left(\mathrm{NO}_{3}\right)_{2} \cdot 6 \mathrm{H}_{2} \mathrm{O} \\
\mathrm{Co}\left(\mathrm{NO}_{3}\right)_{2} \cdot 6 \mathrm{H}_{2} \mathrm{O} \\
\text { Deionized water } \\
\mathrm{KCl} \text { (electrolyte) }\end{array}$ & ITO & Not reported & Pure & Glucose sensing & {$[15]$} \\
\hline Spray pyrolysis & $\begin{array}{c}\mathrm{NiCl}_{2} \cdot 6 \mathrm{H}_{2} \mathrm{O} \\
\mathrm{CoCl}_{2} \cdot 6 \mathrm{H}_{2} \mathrm{O} \\
\text { Deionized water } \\
\end{array}$ & FTO & Not reported & Pure & Supercapacitors & {$[4]$} \\
\hline Solvothermal & $\begin{array}{c}\mathrm{NiCl}_{2} \cdot 6 \mathrm{H}_{2} \mathrm{O} \\
\mathrm{CoCl}_{2} \cdot 6 \mathrm{H}_{2} \mathrm{O} \\
\text { Hexamethylenetetramine }\end{array}$ & FTO & Not reported & Pure & $\begin{array}{l}\text { Water oxidation } \\
\text { reaction }\end{array}$ & {$[17]$} \\
\hline
\end{tabular}

$\sim 230 \mu \mathrm{m}$ and $\sim 210 \mu \mathrm{m}$ in the $X$ and $Y$ directions, respectively; at higher magnification, it is observed that the drops have a size ranging within $45-52 \mu \mathrm{m}$. On the other hand, a uniform and continuous line pattern (in both $X$ and $Y$ directions) was also successfully obtained; see Figures $4(\mathrm{~d})-4(\mathrm{f})$. The width of well-defined lines was $\sim 190 \mu \mathrm{m}$.

The XRD pattern of the F-20-35 films (see Figure 5) exhibits a set of well-defined reflections at $2 \theta$ values of $31.2,36.6,38.9,44.7,59.0$, and $65.2^{\circ}$, which match well with the (022), (113), (222), (004), (115), and (044) crystal planes, respectively, of the pure cubic phase $\mathrm{NiCo}_{2} \mathrm{O}_{4}$ (JCPDS $\# 20$-0781). This result is similar to other reports on the synthesis of single phase $\mathrm{NiCo}_{2} \mathrm{O}_{4}$ film using pulsed laser deposition [16], spray pyrolysis $[4,36]$, hydrothermal route [26], chemical bath deposition [37], electrodeposition [6, 15] and solvothermal route [17], as indicated in Table 1.

Figure 6 shows the XPS analysis of a F-20-35 film, showing that the cobalt $2 \mathrm{p}$ spectrum presents peaks at 780 and $796 \mathrm{eV}$ related to the spin orbit splitting, $2 \mathrm{p} 3 / 2$ and $2 \mathrm{p} 1 / 2$, respectively. Since the binding energies of $\mathrm{Co}^{3+}(779.4 \mathrm{eV})$ and $\mathrm{Co}^{2+}(780.8 \mathrm{eV})$ are very close, the presence of satellite peaks is very important in order to determine the oxidation states of cobalt. In this respect, the observed satellites at 785 and $802 \mathrm{eV}$ can be assigned to the presence of $\mathrm{Co}^{2+}$ ions [8]. On the other hand, the nickel $2 \mathrm{p}$ spectrum contains peaks associated with $2 \mathrm{p} 3 / 2(854 \mathrm{eV})$ and $2 \mathrm{p} 1 / 2(872 \mathrm{eV})$ as well as their respective satellite peaks at 861 and $880 \mathrm{eV}$. The main peak at $854 \mathrm{eV}$ is assigned to octahedral $\mathrm{Ni}^{2+}$ ions, whereas the small shoulder at $856 \mathrm{eV}$ has been ascribed to $\mathrm{Ni}^{3+}$ present in $\mathrm{NiCo}_{2} \mathrm{O}_{4}$ oxide $[2,6]$. The contribution of every metallic cation was determined by a curve-fitting analysis of their respective XPS spectra. According to the quantitative XPS analysis and calculated areas from $2 \mathrm{p} 3 / 2$ peaks of cobalt and nickel, the surface atomic content is $13.9,15.1,6.1$, and $4.4 \%$ for $\mathrm{Co}^{2+}, \mathrm{Co}^{3+}, \mathrm{Ni}^{2+}$, and $\mathrm{Ni}^{3+}$, respectively. This means that the mixed oxidation states of cobalt and nickel favor the charge neutrality and structural stability of the inkjet-printed $\mathrm{NiCo}_{2} \mathrm{O}_{4}$ film, as previously observed for a sol-gel film [2]. 


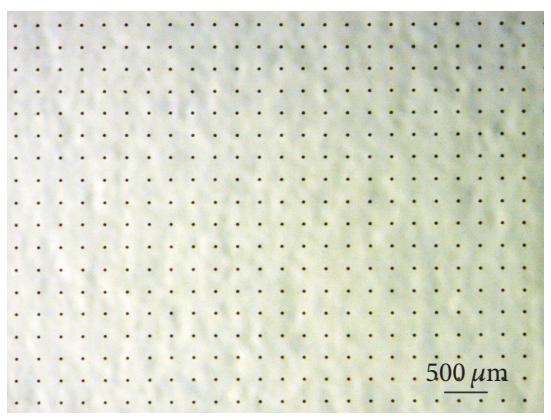

(a)

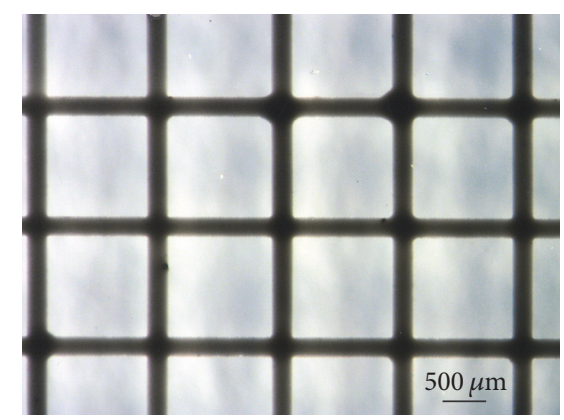

(d)

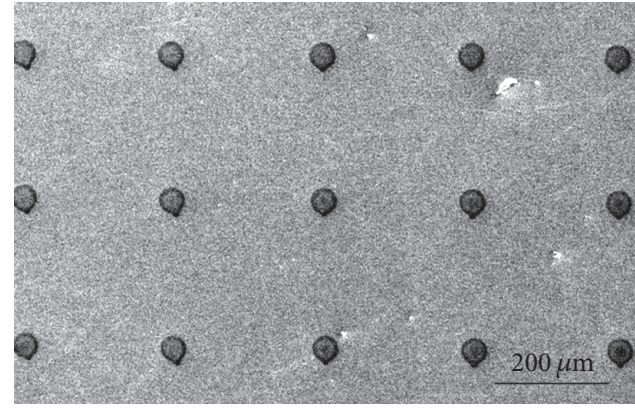

(b)

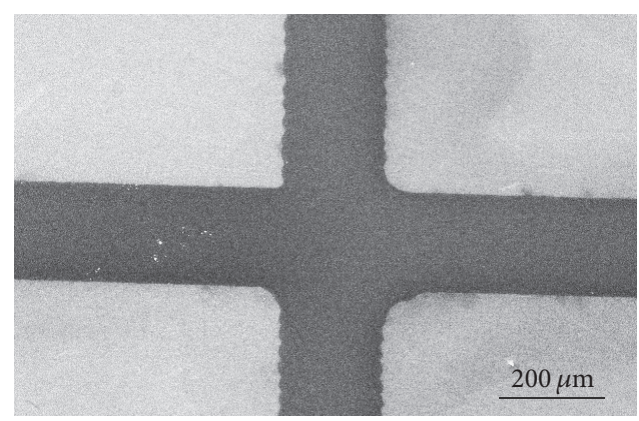

(e)

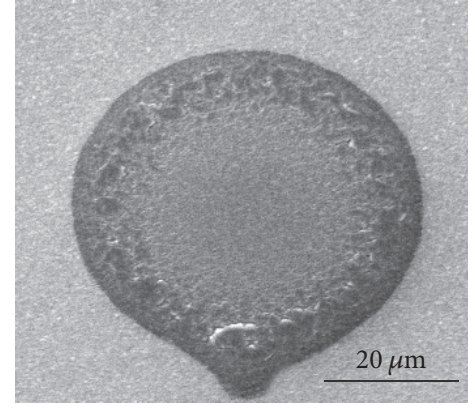

(c)

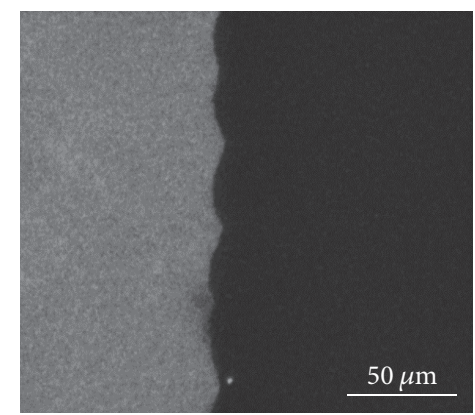

(f)

FIGURE 4: Optical and SEM micrographs of inkjet-printed $\mathrm{NiCo}_{2} \mathrm{O}_{4}$. In (a)-(c), a dot array pattern is presented, and, in (d)-(f), a multiline pattern is depicted.
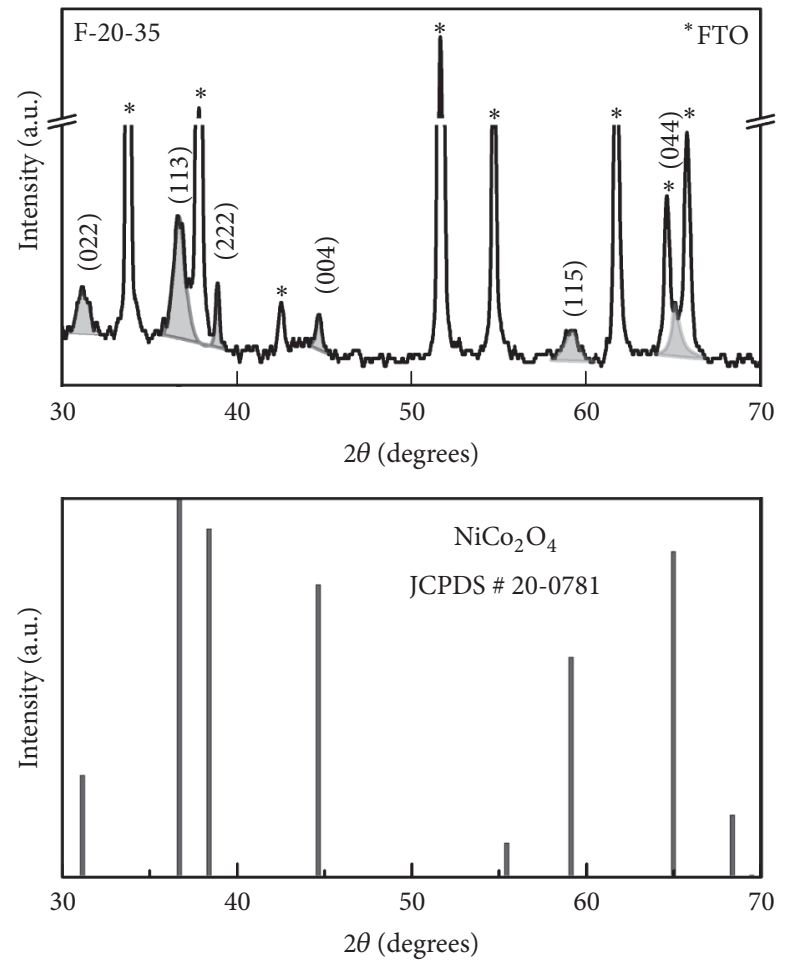

Figure 5: XRD pattern of a $\mathrm{NiCo}_{2} \mathrm{O}_{4}$ film (sample F-20-35) after annealing at $500^{\circ} \mathrm{C}$ for 1 hour. The reflections marked with asterisk correspond to the fluorine-doped tin oxide (FTO) substrate; the line pattern corresponds to the reference JCPDS \# 20-0781.
The electronic absorption spectra obtained from 5 different zones along the $\mathrm{NiCo}_{2} \mathrm{O}_{4}$ film are presented in Figure 7. The absorption profile is as expected from the black color of the oxide, absorbing in the entire visible region of the electromagnetic spectrum, as previously reported [7]. Also, the slight variations in absorbance suggest a good optical homogeneity of the coating. It is known that generally the color of film is an indication of the optical band gap, which can be calculated from the UV-Vis spectrum considering the absorption onset edge and by extrapolation of a straight line to the abscissa axis. Therefore, based on the extended absorption-edge spectrum of $\mathrm{NiCo}_{2} \mathrm{O}_{4}$, the optical band gap of this oxide could be lower than $1.24 \mathrm{eV}$, because the absorbance value is still approximately 0.7 units at $1000 \mathrm{~nm}$. However, the exact band gap of $\mathrm{NiCo}_{2} \mathrm{O}_{4}$ is still controversial: using first-principle calculations, Zhu et al. reported a band gap of $0.2462 \mathrm{eV}$ [10], whereas Shi et al. obtained an indirect band gap of $2.0 \mathrm{eV}$ and a direct gap of $2.1 \mathrm{eV}$ [38]. Dileep et al. utilized high resolution electron energy loss spectroscopy to probe the optical band gaps at the nanoscale in epitaxial thin films with diverse structural order, where the different values were related to indirect, direct, and interband transitions [23].

The film was evaluated in the electrochemical water oxidation reaction, and Figure 8 shows the corresponding linear sweep voltammetry curve. It displays a small peak at $0.4 \mathrm{~V}$ (versus $\mathrm{Ag} / \mathrm{AgCl}$ ) due to the activation process derived of the oxidation of cobalt ions $\left(\mathrm{Co}^{2+} \rightarrow \mathrm{Co}^{3+} \rightarrow \mathrm{Co}^{4+}\right)$ as previously established in the literature [17-19]. Then, the current 


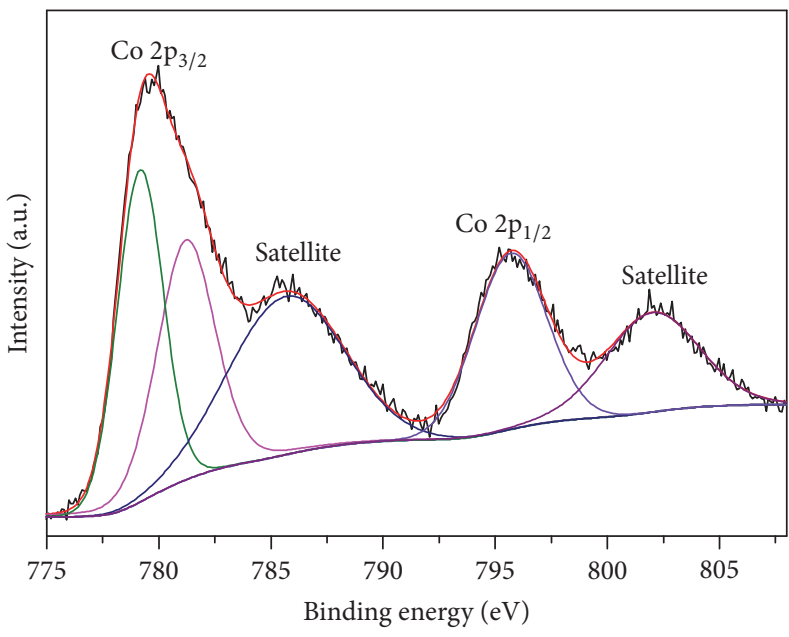

(a)

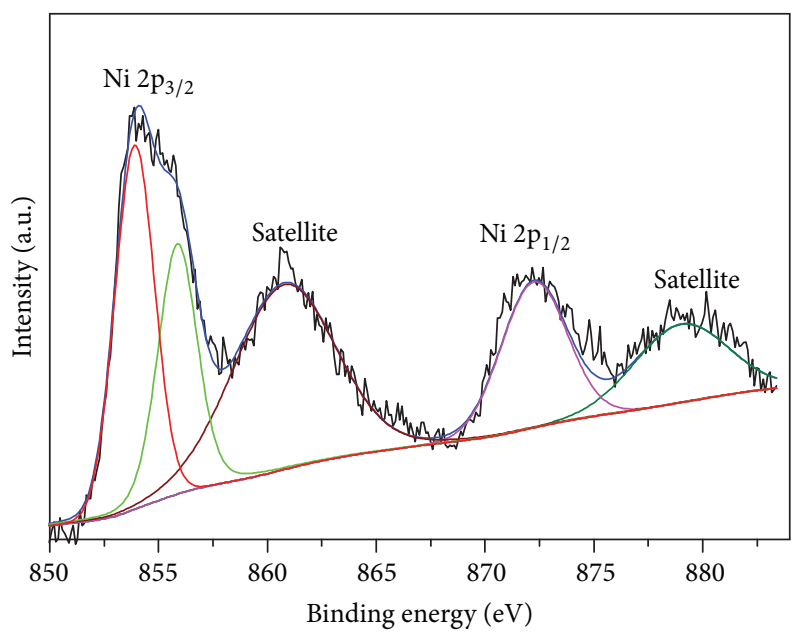

(b)

FIGURE 6: XPS spectra for (a) cobalt 2p and (b) nickel 2p. The colored solid lines below the spectra are derived from curve-fitting analysis.

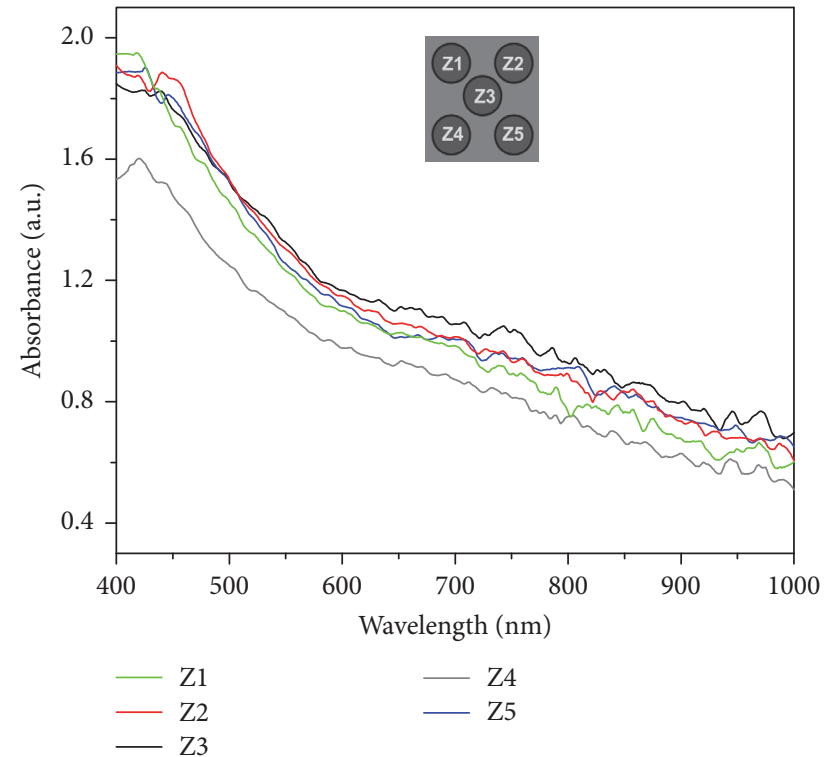

FIGURE 7: UV-Vis electronic absorption spectra measured in 5 different areas of $\mathrm{NiCo}_{2} \mathrm{O}_{4}$ film. The inset drawing indicates the 5 analyzed zones.

increases at an onset potential of $\sim 0.53 \mathrm{~V}$ because the OER proceeds principally via hydroxide ions oxidation $\left(4 \mathrm{OH}^{-} \rightarrow\right.$ $\mathrm{O}_{2}+2 \mathrm{H}_{2} \mathrm{O}+4 \mathrm{e}^{-}$); a current density of $2.7 \mathrm{~mA} / \mathrm{cm}^{2}$ at $0.7 \mathrm{~V}$ versus $\mathrm{Ag} / \mathrm{AgCl}$ (1.67 V versus reversible hydrogen electrode, RHE) was achieved using our inkjet-printed $\mathrm{NiCo}_{2} \mathrm{O}_{4}$ film; this value is similar to earlier reports $[17,20]$. In particular, the value compares well with the current reported for a $\mathrm{NiCo}_{2} \mathrm{O}_{4}$ film (with nanosheets morphology) prepared via a solvothermal route, on the same substrate (FTO) [17]. However, for a more adequate comparison, it is necessary to consider if $\mathrm{NiCo}_{2} \mathrm{O}_{4}$ is obtained as powder or film, the size and shape of the nano- or microstructure (which depends directly on the synthesis conditions), type of substrate used,

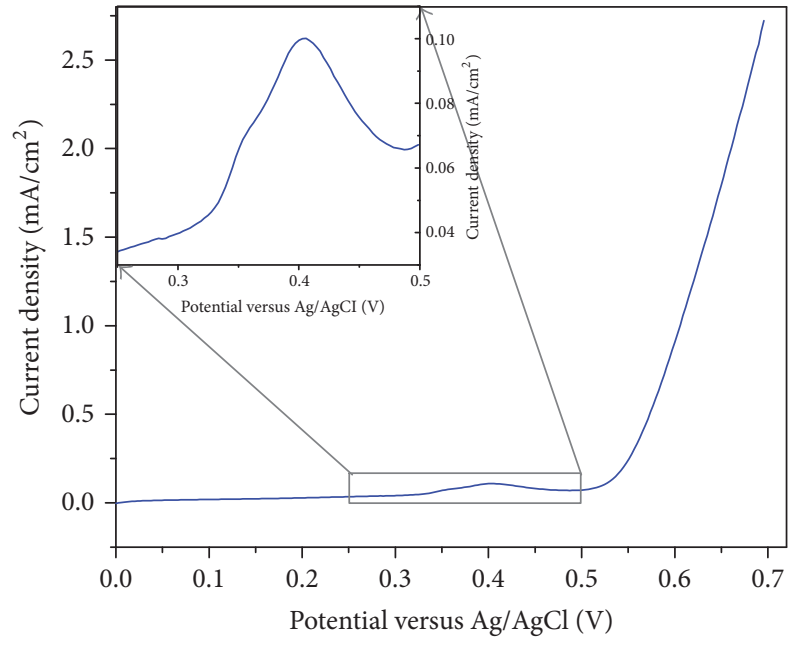

FIGURE 8: Linear sweep voltammetry curve obtained from the analysis of $\mathrm{NiCo}_{2} \mathrm{O}_{4}$ inkjet-printed film.

the fabrication of the electrode, and its geometric and electroactive area. Table S1 (see Supplementary Material available online at https://doi.org/10.1155/2017/9647458) shows a summary of reports on the electrocatalytic properties of $\mathrm{NiCo}_{2} \mathrm{O}_{4}$ prepared by a variety of methods for using in the OER.

Taking these observations into consideration, according to the obtained results and based on the merits of the inkjet printing methodology, this route can be successfully used to scale up very active electrocatalytic materials applied in the clean energy production field.

\section{Conclusions}

Inkjet printing has been efficiently utilized for the preparation of high-quality $\mathrm{NiCo}_{2} \mathrm{O}_{4}$ thin films. The physicochemical properties of the ink, as well as the optimized values of drop spacing $(20 \mu \mathrm{m})$ and jetting voltage $(35 \mathrm{~V})$, were used to 
optimize the uniformity and homogeneity of the fabricated films. XPS results illustrate that the inkjet-printed films have a chemically active redox surface that is composed of a mix of oxidation states, of both cobalt and nickel cations. A current density of $2.7 \mathrm{~mA} / \mathrm{cm}^{2}$ at $0.7 \mathrm{~V}$ was reached using inkjetprinted $\mathrm{NiCo}_{2} \mathrm{O}_{4}$ film in the water oxidation reaction, a value that is comparable with previous reports. Due to the simplicity, low cost, and high performance for preparation of large-area coatings by means of inkjet printing, this is an attractive approach for the fabrication of (photo)electrode films in a variety of solar energy conversion systems.

\section{Conflicts of Interest}

The authors declare that there are no conflicts of interest regarding the publication of this article.

\section{Acknowledgments}

The authors gratefully acknowledge CONACYT, SENER, and IER-UNAM for funding through the Mexican Center for Innovation in Solar Energy (CeMIE-Sol), Project P-18. The authors acknowledge CONACYT for supporting Reyna Dianela Bacelis-Martínez through Ph.D. Scholarship 339456 and Miguel Angel Ruiz-Gómez through Cátedra Project 1710 and INFR-2015-252758. The authors also are grateful for the use of the facilities of the National Laboratory for Nano and Biomaterials of Cinvestav-Mérida supported by Projects FOMIX-Yucatán 2008-108160 and CONACYT LAB-09901 no. 123913. Technical assistance of Daniel Aguilar, Dora Huerta, Willian Cauich, and Ingrid Rodríguez-Gutiérrez is appreciated.

\section{References}

[1] S. Liu, L. Hu, X. Xu, A. A. Al-Ghamdi, and X. Fang, "Nickel cobaltite nanostructures for photoelectric and catalytic applications," Small, vol. 11, no. 34, pp. 4267-4283, 2015.

[2] K. J. Kim and T. Y. Koh, "Cationic structure and charge transport in sol-gel-derived nickel-cobaltite thin films," Journal of Sol-Gel Science and Technology, vol. 77, no. 3, pp. 528-533, 2016.

[3] R. Alcántara, M. Jaraba, P. Lavela, and J. L. Tirado, " $\mathrm{NiCo}_{2} \mathrm{O}_{4}$ spinel: first report on a transition metal oxide for the negative electrode of sodium-ion batteries," Chemistry of Materials, vol. 14, no. 7, pp. 2847-2848, 2002.

[4] R. J. Deokate, R. S. Kalubarme, C. Park, and C. D. Lokhande, "Simple Synthesis of $\mathrm{NiCo}_{2} \mathrm{O}_{4}$ thin films using Spray Pyrolysis for electrochemical supercapacitor application: a Novel approach," Electrochimica Acta, vol. 224, pp. 378-385, 2017.

[5] S.-Y. Tsai, K.-Z. Fung, C.-N. Wei, and H.-Y. Bor, “Thin film deposition of semiconducting Ni-Co oxide spinel with adequate electrical and optical properties for energy application," Journal of Electronic Materials, vol. 43, no. 7, pp. 2584-2587, 2014.

[6] L. Qian, L. Gu, L. Yang, H. Yuan, and D. Xiao, "Direct growth of $\mathrm{NiCo}_{2} \mathrm{O}_{4}$ nanostructures on conductive substrates with enhanced electrocatalytic activity and stability for methanol oxidation," Nanoscale, vol. 5, no. 16, pp. 7388-7396, 2013.

[7] Y. Bitla, Y. Chin, J. Lin et al., "Origin of metallic behavior in $\mathrm{NiCo}_{2} \mathrm{O}_{4}$ ferrimagnet," Scientific Reports, vol. 5, p. 15201, 2015.
[8] J. S. McCloy, W. Jiang, W. Bennett et al., "Electrical and magnetic properties modification in heavy ion irradiated nanograin $\mathrm{Ni}_{x} \mathrm{Co}_{(3-x)} \mathrm{O}_{4}$ films," The Journal of Physical Chemistry C, vol. 119, no. 39, pp. 22465-22476, 2015.

[9] Z. Wu, Y. Zhu, and X. Ji, " $\mathrm{NiCo}_{2} \mathrm{O}_{4}$-based materials for electrochemical supercapacitors," Journal of Materials Chemistry A, vol. 2, no. 36, pp. 14759-14772, 2014.

[10] Y. Zhu, X. Ji, Z. Wu et al., "Spinel $\mathrm{NiCo}_{2} \mathrm{O}_{4}$ for use as a highperformance supercapacitor electrode material: understanding of its electrochemical properties," Journal of Power Sources, vol. 267, pp. 888-900, 2014.

[11] Y. Zhu, Z. Wu, M. Jing et al., "3D network-like mesoporous $\mathrm{NiCo}_{2} \mathrm{O}_{4}$ nanostructures as advanced electrode material for supercapacitors," Electrochimica Acta, vol. 149, pp. 144-151, 2014.

[12] Y. Zhu, J. Wang, Z. Wu et al., "An electrochemical exploration of hollow $\mathrm{NiCo}_{2} \mathrm{O}_{4}$ submicrospheres and its capacitive performances," Journal of Power Sources, vol. 287, pp. 307-315, 2015.

[13] S. Sahoo, S. Ratha, and C. S. Rout, "Spinel $\mathrm{NiCo}_{2} \mathrm{O}_{4}$ nanorods for supercapacitor applications," American Journal of Engineering and Applied Sciences, vol. 8, no. 3, pp. 371-379, 2015.

[14] K. K. Naik, R. T. Khare, R. V. Gelamo et al., "Enhanced electron field emission from $\mathrm{NiCo}_{2} \mathrm{O}_{4}$ nanosheet arrays," Materials Research Express, vol. 2, no. 9, Article ID 095011, 2015.

[15] K. K. Naik, S. Kumar, and C. S. Rout, "Electrodeposited spinel $\mathrm{NiCo}_{2} \mathrm{O}_{4}$ nanosheet arrays for glucose sensing application," RSC Advances, vol. 5, no. 91, pp. 74585-74591, 2015.

[16] P. Silwal, L. Miao, I. Stern, X. Zhou, J. Hu, and D. Ho Kim, “Metal insulator transition with ferrimagnetic order in epitaxial thin films of spinel $\mathrm{NiCo}_{2} \mathrm{O}_{4}$," Applied Physics Letters, vol. 100, no. 3, Article ID 032102, 2012.

[17] H. Shi and G. Zhao, "Water oxidation on spinel $\mathrm{NiCo}_{2} \mathrm{O}_{4}$ nanoneedles anode: microstructures, specific surface character, and the enhanced electrocatalytic performance," The Journal of Physical Chemistry C, vol. 118, no. 45, pp. 25939-25946, 2014.

[18] Y. Tan, C. Wu, H. Lin et al., "Insight the effect of surface Co cations on the electrocatalytic oxygen evolution properties of cobaltite spinels," Electrochimica Acta, vol. 121, pp. 183-187, 2014.

[19] C. Jin, F. Lu, X. Cao, Z. Yang, and R. Yang, "Facile synthesis and excellent electrochemical properties of $\mathrm{NiCo}_{2} \mathrm{O}_{4}$ spinel nanowire arrays as a bifunctional catalyst for the oxygen reduction and evolution reaction," Journal of Materials Chemistry A, vol. 1, no. 39, pp. 12170-12177, 2013.

[20] Y.-Z. Su, Q.-Z. Xu, Q.-S. Zhong, S.-T. Shi, C.-J. Zhang, and C.-W. $\mathrm{Xu}$, "NiCo $\mathrm{O}_{4} / \mathrm{C}$ prepared by one-step intermittent microwave heating method for oxygen evolution reaction in splitter," Journal of Alloys and Compounds, vol. 617, pp. 115-119, 2014.

[21] G. Marbán and T. Valdés-Solís, "Towards the hydrogen economy?" International Journal of Hydrogen Energy, vol. 32, no. 12, pp. 1625-1637, 2007.

[22] X. Gao, H. Zhang, Q. Li et al., "Hierarchical $\mathrm{NiCo}_{2} \mathrm{O}_{4}$ hollow microcuboids as bifunctional electrocatalysts for overall watersplitting," Angewandte Chemie, vol. 55, no. 21, pp. 6290-6294, 2016.

[23] K. Dileep, B. Loukya, P. Silwal, A. Gupta, and R. Datta, "Probing optical band gaps at nanoscale from tetrahedral cation vacancy defects and variation of cation ordering in $\mathrm{NiCo}_{2} \mathrm{O}_{4}$ epitaxial thin films," Journal of Physics D: Applied Physics, vol. 47, no. 40, Article ID 405001, 2014.

[24] P. Silwal, C. La-O-Vorakiat, E. E. M. Chia, D. H. Kim, and D. Talbayev, "Effect of growth temperature on the terahertzfrequency conductivity of the epitaxial transparent conducting 
spinel $\mathrm{NiCo}_{2} \mathrm{O}_{4}$ films," AIP Advances, vol. 3, no. 9, Article ID 092116, 2013.

[25] P. Silwal, L. Miao, J. Hu, L. Spinu, D. Ho Kim, and D. Talbayev, "Thickness dependent structural, magnetic, and electronic properties of the epitaxial films of transparent conducting oxide $\mathrm{NiCo}_{2} \mathrm{O}_{4}$," Journal of Applied Physics, vol. 114, no. 10, Article ID 103704, 2013.

[26] Z. Shi, H. Lu, Q. Liu et al., " $\mathrm{NiCo}_{2} \mathrm{O}_{4}$ nanostructures as a promising alternative for $\mathrm{NiO}$ photocathodes in p-type dyesensitized solar cells with high efficiency," Energy Technology, vol. 2, no. 6, pp. 517-521, 2014.

[27] N. Bahlawane, P. A. Premkumar, J. Feldmann, and K. KohseHöinghaus, "Preparation of doped spinel cobalt oxide thin films and evaluation of their thermal stability," Chemical Vapor Deposition, vol. 13, no. 2-3, pp. 118-122, 2007.

[28] J. Li, F. Rossignol, and J. Macdonald, "Inkjet printing for biosensor fabrication: combining chemistry and technology for advanced manufacturing," Lab on a Chip - Miniaturisation for Chemistry and Biology, vol. 15, no. 12, pp. 2538-2558, 2015.

[29] P. F. Newhouse and B. A. Parkinson, "Combinatorial optimization of spinel $\mathrm{Co}_{3-x} \mathrm{M}_{x} \mathrm{O}_{4} \mathrm{M}=(\mathrm{Al}, \mathrm{Ga}$, In) alloyed thin films prepared by ink jet printing: photoelectrochemical, optical, and structural properties," Journal of Materials Chemistry A, vol. 3 , no. 11, pp. 5901-5907, 2015.

[30] T. Srimongkon, S. Mandai, and T. Enomae, "Application of biomaterials and inkjet printing to develop bacterial culture system," Advances in Materials Science and Engineering, vol. 2015, Article ID 290790, 9 pages, 2015.

[31] C. Ru, J. Luo, S. Xie, and Y. Sun, "A review of non-contact microand nano-printing technologies," Journal of Micromechanics and Microengineering, vol. 24, no. 5, Article ID 053001, 2014.

[32] M. Singh, H. M. Haverinen, P. Dhagat, and G. E. Jabbour, "Inkjet printing-process and its applications," Advanced Materials, vol. 22, no. 6, pp. 673-685, 2010.

[33] S. E. Habas, H. A. S. Platt, M. F. A. M. Van Hest, and D. S. Ginley, "Low-cost inorganic solar cells: from ink to printed device," Chemical Reviews, vol. 110, no. 11, pp. 6571-6594, 2010.

[34] Glycerine Producers' Association, Physical Properties of Glycerine and Its Solutions, Glycerine Producers' Association, New York, NY, USA, 1963.

[35] Dimatix Materials Printer DMP-2800 FAQs, Fujifilm Dimatix Inc. pp. 1-5, 2008.

[36] D. P. Lapham and J. L. Lapham, "The porosity of $\mathrm{NiCo}_{2} \mathrm{O}_{4}$ films and powders by three common preparation techniques," Microporous and Mesoporous Materials, vol. 223, pp. 35-45, 2016.

[37] R. B. Waghmode and A. P. Torane, "Role of deposition time on synthesis of high-performance $\mathrm{NiCo}_{2} \mathrm{O}_{4}$ supercapacitors," Journal of Materials Science: Materials in Electronics, vol. 28, no. 13, pp. 9575-9583, 2017.

[38] X. Shi, S. L. Bernasek, and A. Selloni, "Formation, electronic structure, and defects of Ni substituted spinel cobalt oxide: a DFT+U study," Journal of Physical Chemistry C, vol. 120, no. 27, pp. 14892-14898, 2016. 

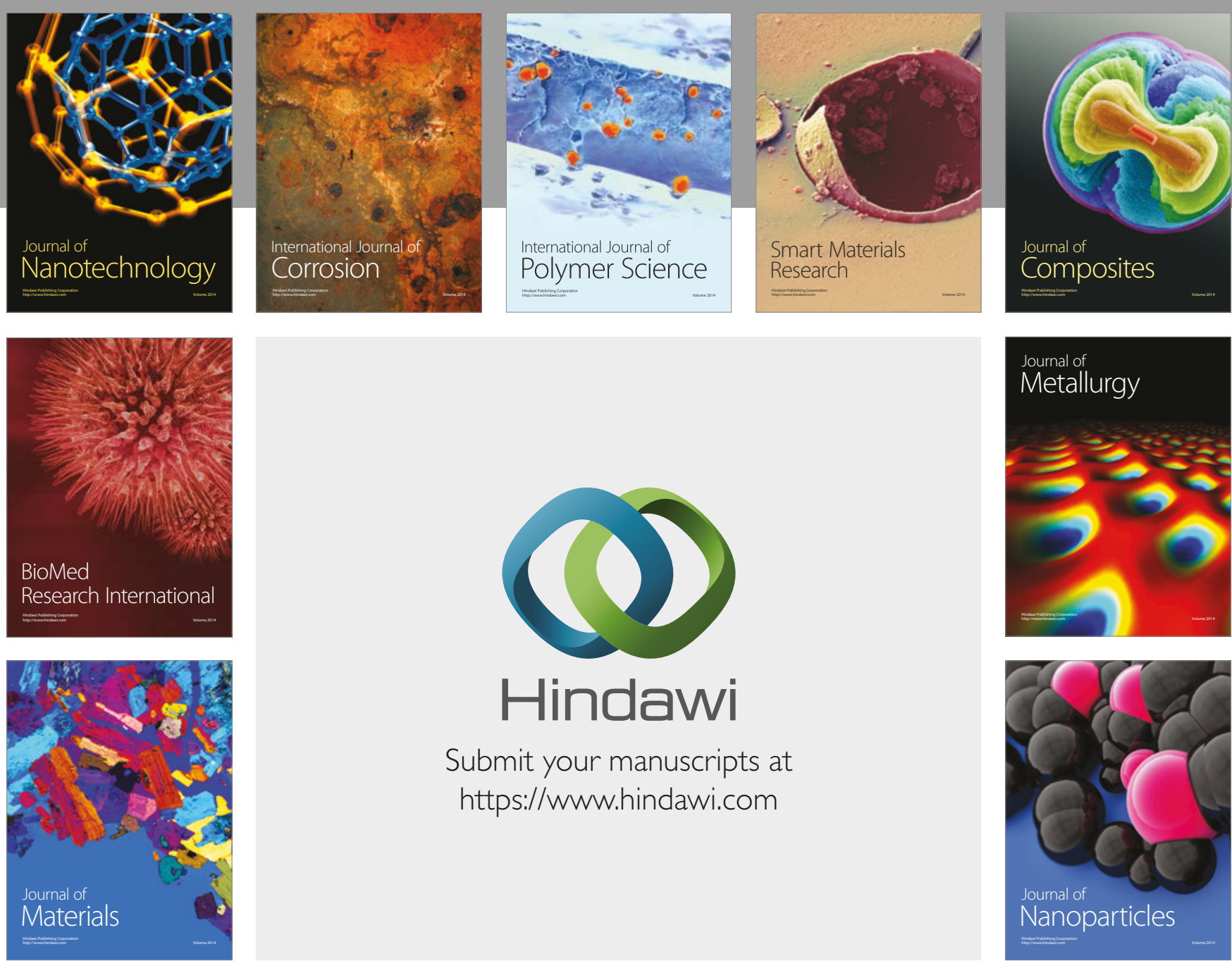

\section{Hindawi}

Submit your manuscripts at

https://www.hindawi.com
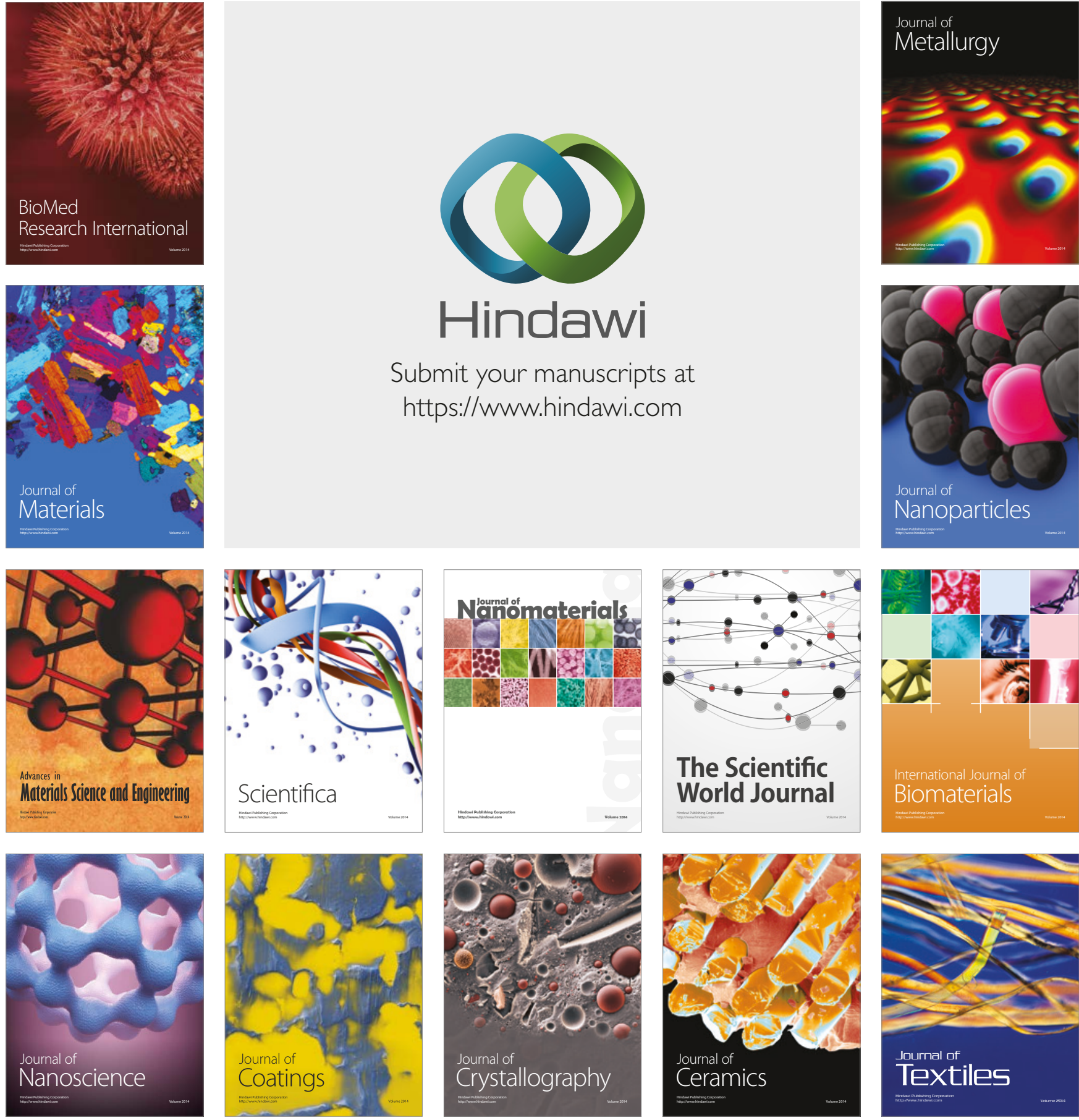

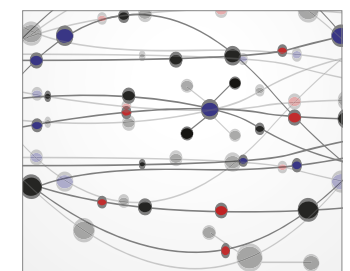

The Scientific World Journal
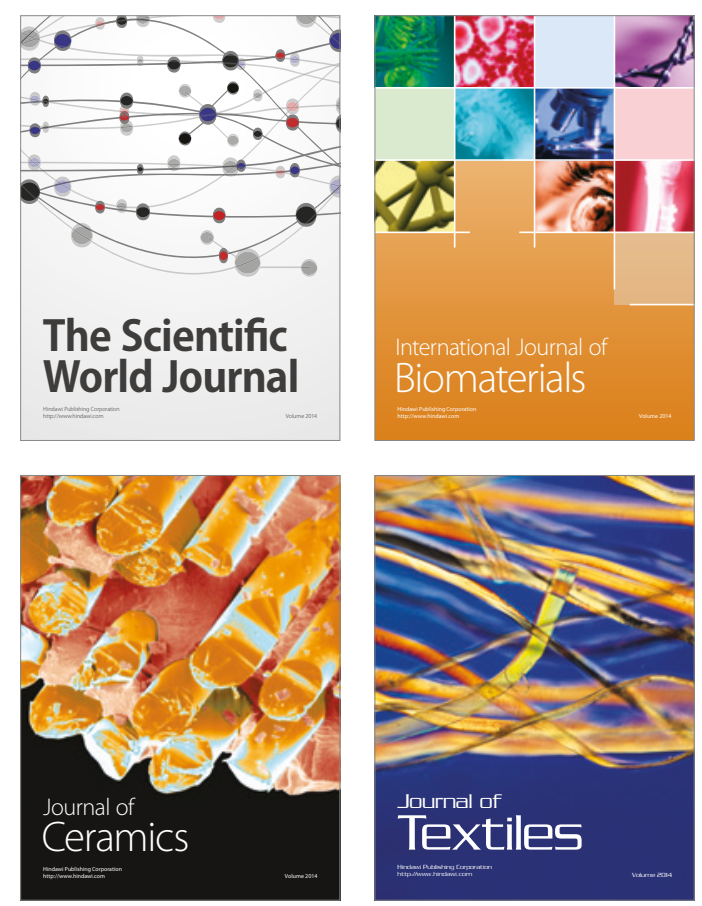